\title{
Formální odlišnost v multimediálním artefaktu a s ním spojená proměna narativu díla
}

\author{
Formal difference of multimedia artifact and related change of the narrative \\ Vladimíra Zikmundová
}

\begin{abstract}
Abstrakt: Autorka v příspěvku referuje o částečných výsledcích empirického výzkumu, který sledoval proměnu narativu u dynamického multimediálního artefaktu podbarveného různou zvukovou stopou. Základní otázkou výzkumu bylo, jakým způsobem mohou multimediální obrazy ovlivňovat kultivaci vizuální gramotnosti a proces poznávání. Výzkum byl založen na kvalitativní analýze výpovědí respondentů popisujících odlišnosti výtvarného zážitku. Ukázalo se, že narativ spojený s verzemi artefaktu se podstatně liší.
\end{abstract}

Klíčová slova: multimédia, vizuální gramotnost, rozmanitá gramotnost, výtvarná výchova

\begin{abstract}
The author of the paper refers to partial results of the empirical research which is focusing on the change of the narrative of dynamic multimedia artifact with a different sound. The basic question of the research was how can multimedia images influence cultivation of the visual literacy and the process of gaining knowledge. The research was based on the qualitative analysis of statements of respondents who described the change of their pictorial experience. The outcomes show that the narrative related to different versions of the artifact significantly differs.
\end{abstract}

Keywords: multimedia, visual literacy, multiliteracy, art education

\section{1 Úvod}

Následující text shrnuje dílčí závěry výzkumu, v jehož centru pozornosti stojí artefakty, jejichž př́jem je u diváka realizován prostřednictvím několika smyslů a jsou tvořeny za pomoci digitálních technologií - multimédií. Multimediální základ těchto forem umožňuje jejich proměnlivost, která sebou nese i kvalitativní odlišnosti v recipientově zážitku. Jak píše Duncum „ pokud vypneme zvukovou stopu u videohry, shledáme, jak zásadní jsou zvukové efekty pro zážitek z ní" (Duncum, 2004, s. 252, překlad autorky). Duncum vyjadřuje potřebu výchovy, která pěstuje gramotnost získávanou prostřednictvím rozmanitých smyslů. Multimodalitu a multimodální analýzu pak Duncum označuje jako inovativní př́stup k reprezentaci, komunikaci a interakci ${ }^{1}$. S digitálními médii můžeme také zaměňovat jednotlivé komponenty obrazu. Pak se chováme jako DJ, který mixuje samply se záměrem získat novou formu prostřednictvím recyklování existujících zvukových stop a měnit jejich původní poslání (Bourriaud, 2004, s. 9-11).

Variabilita je spolu s číselnou reprezentací a modularitou jedním z hlavních principů nových médií. To znamená, že ,neomediální objekt není něco fixního jednou proždy, ale něco, co může existovat v odlišných, potenciálně nekonečných verzích“ (Manovich, 2001, s. 36). Tato vlastnost nových médií hraje významnou roli v našem experimentu.

\footnotetext{
${ }^{1}$ Koncept multimodality je rozpracováván mnoha autory, kteří jsou citováni v Duncumově textu. Z posledních publikací doporučujeme např. antologii uspořádanou Carey Jewitt (Jewitt, 2009).
} 


\section{Objekt experimentu}

Základem experimentu se stalo multimediální dílo postavené na rozpohybování obrazů Salvadora Dalího v programu Adobe Flash ${ }^{2}$. Tento program umožňuje tvůrci vytvářet dynamické sekvence např́klad z fotografií stažených z internetu. Vstupní materiály lze použít v nezměněné podobě nebo z nich vybírat části a kombinovat je ve formě koláže proměnlivé $\mathrm{v}$ čase. Tato vlastnost programu byla aplikována v př́padě animace, kterou vytvořila studentka v předmětu Základy multimediální tvorby na Fakultě pedagogické Západočeské univerzity v Plzni (dále KVK). Animace je 94,4s dlouhá a obsahuje 1140 framů uspořádaných v 7 scénách. Každá scéna používá jako pozadí 1 malbu Salvadora Dalího. Mezi nimi rozeznáváme Hořicí žirafu (1935), Tři mladé surealistické ženy držicí v rukou kǔži orchestru (1936), Geopolitica (1943) a Krista Sv. Jana z Kř̌že (1951). Hlavní postavy animace jsou 2 figury. Figura 1 je malá karikatura Dalího od neznámého autora držící v rukou štětec a figura 2 je vysoká bytost oděná do světlé modré. Figura 2 je převzata z Dalího obrazu Hořicí žirafa. Při sledování animace vidíme, že figura 2 sleduje figuru 1 postupně ze scény do scény (žádný z obrazů v pozadí není použit $2 \mathrm{x}$ ), takže výsledek nám zprostředkuje pocit kontinuálního pohybu zachyceného prostřednictvím několika záběrů. Vybrané detaily v obraze na pozadí jsou animovány (např́íklad mávající ruce). Na konci figura 1 je brána do náručí antropomorfické postavy a vhozena do jednoho z šuplíků na jejím těle.

Toto je krátký popis toho, co vidíme. Ale klíčovou komponentou výzkumu je zvuk. Abychom přesněji popsali základ zkoumaného materiálu, je třeba říci, že animace existuje ve dvou verzích. Když autorka animace konzultovala poprvé rozpracovaný materiál, doplnila obraz hudbou veselou až jásavou s reggae a jazzovými rytmy. Ve finální verzi však použila naprosto odlišný zvuk, který označila jako „více přiléhavý“ vizuální formě. Tato hudba zněla dramaticky a disharmonicky. Při reflexi práce v semináři jsme zjistili, že používáme zcela jiné deskriptory pro zachycení obsahu animace.

\section{Experiment}

Tímto jsme se dostali k velmi inspirativnímu materiálu pro další zkoumání. Navrhli jsme výzkum založený na předpokladu, že stejný vizuální obraz může zprostředkovat odlišné významy, pokud je doprovázen různou zvukovou stopou. V první fázi experimentu jsme ukázali obě varianty animace skupině participantů a požádali je o písemný záznam zážitku z animací. Skupina se rekrutovala z 92 studentů z učitelských a neučitelských studijních programů KVK se zaměřením na vzdělávání ve výtvarné oblasti ${ }^{3}$. Výpovědi jsou v současné době v procesu kvalitativni analýzy s oporou v zakotvené teorii (Strauss \& Corbin, 1999).

Pokud hovoříme o zážitku, máme na mysli výtvarný zážitek (Slavík, 2001, s. 255-264). Slavík uvádí, že výtvarný zážitek můžeme pojímat prostřednictvím 4 úrovní: (a) významu, který nám ř́ká, CO dílo zobrazuje, či k čemu se vztahuje; (b) konstrukce, která odpovídá na otázku, JAK a jakými prostředky bylo dílo zobrazeno; (c) empatie, tedy jak divákovo vnímání obrazu koresponduje s původním záměrem autora (tato úroveň je také důležitá při sociálním vyjednávání významu pojímání obrazu různými recipienty); a konečně se jedná o úroveň (d) prožitku, který je ve své podstatě nepřenositelný a může být pouze popsán nebo zprostředkován různými typy vyjádření jako např. slovy, tancem atd. Exprese jako ,př́íznačný

\footnotetext{
${ }^{2} \mathrm{~V}$ př́ípadě uvedené animace se jednalo o zpracování ve verzi 8.0 předchozího výrobce Macromedia Flash C)1993-2005, Macromedia Inc.

${ }^{3}$ Záměrně neuvádíme zastoupení mužů a žen, protože zkoumání genderových stereotypů není prozatím cílem výzkumu.
} 
a zobecňující typ reprezentačních aktivit“ je pak základem naplňování vzdělávacích cílů v estetických oborech (Slavík, 2011).

V této první fázi experimentu jsme skupině respondentů pouštěli obě verze animací v pořadí jejich vzniku. Finální „dramatická“ verze předcházela verzi „veselé“. Při analýze výpovědí jsme zjistili, že vnímání obrazu, a tudíž narativ díla, může být dramaticky pozměněn v kontextu se změnou zvukové stopy. $V$ těch př́padech, kde účastníci popisovali zvukovou stopu samotnou, používali termíny jako „depresivní“, „dramatická““, strašidelná““, „hektická““, „,zmatená“. Pro druhou variantu zvuku používali slova jako „,veselá“, „radostná“, ,jásavá““, „,bezstarostnác, „hravá“ a „pozitivní“. Tato adjektiva nabyla velkého významu ve vztahu k popisu zážitku. V následujících dvou kapitolách citujeme části výpovědí, které charakterizují odlišnosti v interpretaci verzí. Analýza je prozatím prováděna na kvalitativní úrovni, ale ukazuje se, že design výzkumu je třeba vhodně doplnit také kvantitativními metodami, které budou schopny popsat výsledky výzkumu z hlediska četnosti použivaných pojmů a odlišností v preferencích (analýza rozptylu).

\subsection{Animace 1-dramatická verze}

Animace sprvní hudbou mi naháněla husi kůži. Postava pronásledující Dalího mi připomínala Zombii, která už ho skoro dohání, aby ho roztrhala na kousky a zabila ho...

Popis první verze často obsahuje negativní konotace. Figura 2 reprezentuje kohosi, kdo pronásleduje a ohrožuje figuru 1. Toto nebezpečí je často popsáno jako smrtelné. Někteří respondenti pokládají dramatickou hudbu za iritující s fyzickými symptomy odporu a někteří vyjadřují potřebu animaci ukončit.

Depresivní, hororové, splašené se strachem z odchytu. V této animaci se př́běh zdá být delší...

Zjišt'ujeme, že zvuková stopa ovlivňuje subjektivní vnímání času a délky trvání obrazu, přestože obě verze animace jsou ve skutečnosti stejně dlouhé. První animace označená jako depresivní se v některých př́ípadech zdála delší. Proto jsme se rozhodli tuto skutečnost ověřit v další fázi výzkumu, kterou popíšeme v kapitole 4.1.

Technický zvuk v pozadí dělá dojem jakoby postavy byli roboti, jakoby už nebyli živí...

Kategorie robotů, mumií a zombií zvýrazňují v describci pocit neživotnosti zejména figury 2. Zaznamenali jsme i připodobnění atmosféry příběhu k Čapkově R.U.R. nebo Orwellově 1984.

Chmurná animace... pocit neklidu... psychóza jakoby se Dalí ztratil ve svých snech a fantaziích, které ho straši a pronásledují... snaži se uniknout, ale ony jsou na každém kroku...

Pro intenzitu vyjádření absurdity a bezvýchodnosti př́iběhu se v popisu často vyskytuje termín „noční můra“. Uvedená citace také reprezentuje ty výpovědi, ve kterých nacházíme subjektivní pocit temnoty animace, ztráty světla, na který má použitý zvuk přímý vliv (více kapitola 3.2).

Přestože se mi hudba nelíbila, hodila se kanimaci více než ta druhá. Ale nebyla mi př́jemná...

Na úrovni empatické složky zážitku koresponduje daná vizuální forma se zvukovou stopou. Významná část účastníků vysvětluje shodu dramatické verze s vizuální složkou „podivností“ Dalího tvorby, přestože převážná většina těchto tvrzení je následována vyjádřením ve smyslu rozporu mezi libostí a přiléhavostí. 


\subsection{Animace 2 - veselá verze}

Je to velmi veselá, hezká, „radio friendly“ verze. Myslím, že se lidem bude líbit! Také tato hudba se hodi kobrazu, ale ne tak jako první. Vic se mi líbi první, protože ten velmi abstraktní zvuk se lépe hodí k dílu umělce a spojuje obě části...

Toto tvrzení předjímá př́pady popisů druhé verze $s$,veselou“ hudbou, jak jsme ji pracovně pojmenovali. Převážná většina výpovědí vyjadřuje úlevu, hudba podle nich zní př́ijemně, a proto se k druhé verzi pojí pozitivnější konotace.

Honička se tu zdá být víc jako hra. Ti dva se možná baví o prázdninách. Naprosto veselejší pocit...

$\mathrm{V}$ druhé animaci se honička proměňuje z života ohrožujícího aktu do aktu hry. K tomuto se pojí výrazy jako „na honěnou“, „slepá bába“ a „schovávaná“. Fakt, že figura 2 následuje figuru 1 ze scény do scény, je vnímán více jako škádlení namísto hrozby nebo stíhání. Často se objevuje téma cestování a dobrodružství.

Animace byla o moc veselejší, působilo to na mě jako vtip. Nebylo to vážné...

Oproti předchozí verzi, která je přirovnávána spíše k tragedii, je druhá verze popisována často jako komedie, groteska či karikatura. Atmosféra prŕíběhu je interpretována jako bezstarostná.

Zvláštní je, že postavy př́běhu vypadají, jakoby tancovaly. Figury jsou plné života a energie...

$\mathrm{V}$ př́ípadě druhé animace je zřetelný posun ke vnímání postav jako živých a svěžích. Rytmus hudby způsobuje, že pohyb figur je často pojímán jako tanec.

Pocity: láska, teplo, slunce...

Druhá verze animace je často vztažena k pocitu tepla v opozici k finální dramatické verzi, která evokuje pochmurnou a tmavou atmosféru. Tento fakt nás vedl k další fázi výzkumu, která se zaměřila na vliv multisenzorického zážitku na poznávací procesy.

\section{Fáze 2 experimentu}

V další fázi výzkumu jsme připravili 6 expertních skupin z prostředí středních a vysokých škol s výtvarným zaměřením a pedagogů ze všech stupňů škol se zahrnutím základních uměleckých škol. Celkový počet respondentů byl 138.

\subsection{Subjektivní vnímání času}

$\mathrm{V}$ předchozí kapitole jsme uvedli, že animace s dramatickou hudbou byla často subjektivně vnímána jako delší. Proto jsme v této fázi výzkumu ve 2 skupinách zaměnili pořadí animací. Ukazuje se, že dramatická verze je subjektivně vnímána jako delší bez ohledu na pořadí prezentace verzí. Tento fakt chceme ještě oveřrit v následujících fázích výzkumu, kdy hodláme měřit subjektivní délku animace u skupin, které neuvidí obě verze najednou.

\subsection{Vliv zvukové komponenty na vizuální vnímání obrazu}

Výpovědi $\mathrm{z}$ předchozích kapitol, nás inspirovaly $\mathrm{k}$ vytvoření takového nástroje, který by testoval, jaká barevnost více „sedi“" $\mathrm{k}$ dané verzi animace. Navrhli jsme sadu 8 barevných tabulek, které obsahovaly výtažky barev scén animace. Účastníci výzkumu měli vždy ke každé verzi přiřadit tabulku s barevností, která podle nich nejlépe vystihovala charakter animace. Ukázalo se, že podle našeho předpokladu s výraznou převahou převládá výběr tabulek 
s tmavými a spíše studenými tóny barev u dramatické animace a jasnými, světlými a teplými tóny u animace druhé. Domníváme se, že v závislosti na proměně komponent multimediálního díla můžeme ovlivňovat jeho vnímání, a tím i potenci recipienta $\mathrm{k}$ učení. Toto tvrzení by bylo vhodné potvrdit sondou zaměřenou na subjektivní vnímání animace podle aktuálního emotivního vyladění recipienta, jenž může do charakteru zážitku výrazně zasáhnout.

\section{Shrnutí}

Předložené prozatímní výsledky výzkumu dokládají, že význam toho, co „vidíme“, není jednoznačně inherentní danému sdělení. Zejména u děl multimediálního charakteru, která jsou popsaným způsobem variabilní, změna jedné komponenty ovlivní celkový význam pro recipienta a kvalitu jeho zážitku. Přestože vizuální forma zůstává stejná a způsob vizuální reprezentace děje (syžet) se nemění, narativ spojený s výkladem zážitku se zásadně proměňuje (Arbanová, 2009). Dobrým př́íkladem tohoto jevu v mediální oblasti jsou odlišné způsoby převyprávění událostí $\mathrm{v}$ televizních zprávách na různých stanicích (od neutrálních po silně emotivní). Naším experimentem chceme přispět k objasnění důležitosti tzv. learning-bydoing v oblasti multimediální tvorby, na které je $\mathrm{v}$ naší společnosti v posledních letech založena prakticky veškerá mediální komunikace.

\section{Literatura}

Arbanová, L. (2009). Filmový obraz jako předmět výchovy a vzdělávání (Disertační práce). Praha: PdF UK v Praze.

Bourriaud, N. (2004). Postprodukce. Praha: Tranzit.

Duncum, P. (2004). Visual culture isn't just visual: Multiliteracy, multimodality and meaning. Studies in Art Education: A Journal of Issues and Research, 45(3), 252-264.

Jewitt, C. (Ed). (2009). The Routledge handbook of multimodal analysis. London: Routledge.

Manovich, L. (2001). The languages of new media. Cambridge, London: MIT press.

Slavík, J. (2011). K předmětu didaktik v estetických oborech vzdělávání. Pedagogická orientace, $21(2), 207-225$.

Slavík, J. (2001). Umění zážitku, zážitek umění. Praha: PdF UK v Praze.

Strauss, A., \& Corbin, J. (1999). Základy kvalitativního výzkumu. Boskovice: Albert.

\section{Kontakt}

PhDr. Vladimíra Zikmundová, Ph.D.

Západočeská univerzita v Plzni

Fakulta pedagogická, Katedra výtvarné kultury

Chodské nám. 1, 30614 Plzeň

e-mail: vlazik@kvk.zcu.cz

\section{Bibliografické údaje}

Zikmundová, V. (2011). Formální odlišnost v multimediálním artefaktu a s ním spojená proměna narativu díla. In T. Janík, P. Knecht, \& S. Šebestová (Eds.), Smišený design v pedagogickém výzkumu: Sbornik př́spěvků z 19. výroční konference České asociace pedagogického výzkumu (s. 511-515). Brno: Masarykova univerzita.

Dostupné z: http://www.ped.muni.cz/capv2011/sbornikprispevku/zikmundova.pdf doi: 10.5817/PdF.P210-CAPV-2012-87 